\title{
Endocrine dysfunctions may be sequelae of snake bite
}

\author{
Kaushik Kar ${ }^{1}$, Sandipan Mukherjee ${ }^{2}$ \\ ${ }^{1}$ Associate Professor, Department of Biochemistry, Calcutta National Medical College. Kolkata, West Bengal, India, \\ ${ }^{2}$ Senior Resident, Department of General Medicine, Tamluk Hospital, Purba Midnapur, Dist Midnapur, West Bengal, \\ India
}

Background: At present snakebite has become a serious health problem in India. The actual incidence of mortality and morbidity related to the snakebite are not reported properly. Further, the most neglected part is the long term endocrine dysfunctions in survivors of snake bite. Aims and Objectives: To evaluate serum fT4, TSH, cortisol, prolactin, and testosterone levels in snake bite survivors after 3 and 6 months of snakebite. Materials and Methods: Forty-five survivors of russels viper bite patients were selected for the study according to inclusion and exclusion criteria. Admitted patients were treated accordingly and discharged in stable condition. The hormonal status were analysed and they have been followed up after 3 and 6 months. Results: Significant decrease in serum cortisol and prolactin were observed in survivors of russels viper bite patients particularly in them whose mean serum creatinine was more than $1.2 \mathrm{mg} / \mathrm{dl}$ and systolic blood pressure was $<110 \mathrm{~mm}$ of $\mathrm{Hg}$ and diastolic Blood pressure was $<70 \mathrm{~mm}$ of $\mathrm{Hg}$. Conclusion: Measurement of long term hormonal status like serum cortisol and prolactin can be beneficial in survivors of hematotoxic snake bite patients.

Key words: Snake bite; Survivors; Endocrine dysfunctions; Serum creatinine; Blood pressure

\section{Access this article online}

Website:

http://nepjol.info/index.php/AJMS DOI: 10.3126/ajms.v12i9.36990

E-ISSN: 2091-0576

P-ISSN: 2467-9100

Copyright (c) 2021 Asian Journal of Medical Sciences

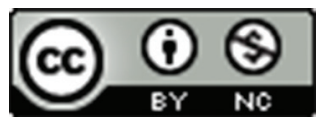

This work is licensed under a Creative Commons Attribution-NonCommercial 4.0 International License.

\section{INTRODUCTION}

Snakebites are well known serious public health problem in the tropical countries ${ }^{1}$ and considered as occupational hazards among the agricultural workers. ${ }^{2}$ Recent studies documented that in India, the death due to snakebite accounts about 50000 annually. ${ }^{3}$ An accurate measure of this global burden of snakebite remains elusive. ${ }^{4,5}$

Many developing countries consider the snakebite as a neglected tropical disease. ${ }^{6,7}$ The incidence as well as mortality and morbidity associated with venomous snakes are only reflected by some sporadic reports. The neglected part also remains on survivors on envenomation. ${ }^{6}$ Related studies have documented the development of Sheehans like syndrome associated with chronic hypopituitarism following Russel viper envenomation. ${ }^{8,9}$ Bites by Russels viper can cause, neurotoxicity, vasculotoxicity and myotoxicity. ${ }^{10}$ Toxicity due to viper bite causes the bleeding from mucocutaneous sites, hemolysis, acute kidney injury and shock. ${ }^{11}$ Some studies evidenced that mortality increased by 1.3 to 2.2 fold in patients suffering from hypopituitarism, when compared with age and sex matched cohorts. ${ }^{12}$ Snakebite is an uncommon cause of hypopituitarism stated by them. ${ }^{13}$ Chatterjee et al., observed hypopituitarism among the snakebite patients. ${ }^{14}$ Involvement of multiple endocrine glands can occur during acute stage or after several months of snake bite. ${ }^{15}$ Acute adrenal insufficiency was also observed by some authors after snakebite. ${ }^{16}$

By the review of above literatures, and limited studies observed at our region, we arranged the present study, to observe the prevalence of endocrine dysfunctions among survivors of Russels viper bite. 


\section{MATERIALS AND METHODS}

The current hospital based, cross sectional and observational study was conducted in the Department of Medicine and Department of Biochemistry of Calcutta National Medical College, Kolkata.

Selection of study group- The study group includes 45 survivors of hematotoxic snake bite (age group between 14-60 years) patients admitted in Medicine ward matched with inclusion and exclusion criteria. Seven patients have not survived till the study period and eight patients did not attend the follow up programme. Admitted patients were managed in ward and discharged in hemodynamically stable condition. Further they have been followed up in Medicine Outpatient Department.

Informed consents were taken from patients and study was approved from Institutional Ethics Committee (IEC), according to the protocol of Helsinki declaration 1975, modified on 1983.

Investigation and management protocol followed- A clinical history taking and a complete physical examination were done in each case.

Inclusion criteria were all patients admitted with vasculotoxic snake bite within 72 hours.

The exclusion criteria included, Acute hypopituitarism developed after snakebite, patients with known endocrine disorder, known liver or kidney diseases, extremely poor general condition.

General examinations: All the participants were conscious, oriented. Pulse, respiration, temperature, blood pressure, pallor, and oedema were noted in them. Following investigations were performed at admission for all patients.

Blood- Whole blood clotting time (WBCT), haemoglobin, (S) creatinine, total and differential leucocyte count, platelet count, RBC count, bleeding time, clotting time, prothrombin time, activated partial thromboplastin time, and international normalised ratio (INR), kidney and liver function tests and (S) sodium and potassium.

Urine microscopy, urine albumin.

The radiological investigations included X-ray chest, ultrasonography of the abdomen.

Patients were treated conservatively. 10 vials of Antivenom Serum (AVS) given initially and clinical assessment done periodically. After 6 hours WBCT measured again and 20 vials of AVS was administered accordingly. Hemodialysis was done for selected patients whose creatinine levels were higher, hypervolemia and hyperkalaemia. Inotropic support was given to patients who developed shock like features. After the recovery, patients were discharged with hemodyamically stable condition and further asked to follow up in OPD and were assessed clinically.

Dialysis: Six $(20 \%)$ patients required hemodialysis as part of treatment while $24(80 \%)$ didn't. The following investigations were done at 3 and 6 months follow up to find out any endocrinological abnormalities:

(S) fT4, TSH, Cortisol, Prolactin, and Testosterone.

Measurements of Biochemical parameters: (S)fT4 was measured by competitive enzyme immunoassay (Tosoh India), ${ }^{17}$ (S) TSH was measured by solid phase enzyme linked immunosorbent assay (Accu Diag ${ }^{\text {TM }}$ TSH, USA). ${ }^{18}(\mathrm{~S})$ cortisol was analysed by competitive enzyme immunoassay (Monobind Inc, USA). ${ }^{19}$ (S) prolactin was estimated by solid phase enzyme linked immunosorbent assay (AccuDiag ${ }^{\text {TM}}$-Prolactin). ${ }^{20}$ Furthermore (S) testosterone was measured by competitive enzyme immunoassay (Calbiotech, India). ${ }^{21}$

Patients were divided into subgroups according to age, sex, haemoglobin, creatinine, systolic and diastolic blood pressure, WBCT, dialysis and AVS treatment for comparison and followed up for 3 and 6 months for study.

Data collection and processing for statistical analysis: Statistical analysis was aimed

- To assess the significance of difference between the mean values of serum cortisol, prolactin and testosterone between 3 and 6 months follow up in complete study population.

- To find out the same significance among viper bite patients with serum creatinine $>1.2 \mathrm{mg} / \mathrm{dl}$ on admission and with systolic blood pressure $<110$ and/or diastolic blood pressure $<70 \mathrm{~mm}$ of $\mathrm{Hg}$ on admission.

- Data was collected after estimation of biochemical parameters and processed for calculation of mean and standard deviations as well as for rest of the statistical analysis.

- Outcome measures are tabulated as results.

Statistical methods: Continuous variables were expressed as mean (Std deviation) and the differences were accomplished by comparison via unpaired $t$ test or one-way ANOVA as 
appropriate. A significant difference was considered as $\mathrm{p}<0.05$. Data was analysed using SPSS 20 software.

\section{RESULTS}

Table 1 has shown the demographic profile and biochemical parameters of snake bite patients included in the present study. The following features were observed on admission.

Thirty snake bite patients were included in the present study. Among them 11 patients had haemoglobin level $<10 \mathrm{gm} / \mathrm{dl}$ and 19 patients had $>10 \mathrm{gm} / \mathrm{dl}(\mathrm{S})$ creatinine was $<1.2 \mathrm{mg} / \mathrm{dl}$ only in 5 patients whereas the same was $>1.2 \mathrm{mg} / \mathrm{dl}$ in 25 patients. Systolic blood pressure was $<110 \mathrm{~mm}$ of $\mathrm{Hg}$ in 12 patients whereas the same was more than $110 \mathrm{~mm}$ of $\mathrm{Hg}$ in 18 patients. 16 patients were having diastolic blood pressure $<70 \mathrm{~mm}$ of $\mathrm{Hg}$ whereas 14 patients had $>70 \mathrm{~mm}$ of $\mathrm{Hg}$. Platelet count was $<$ one lakh $/ \mathrm{cmm}$ in 13 patients whereas the same was more than 1 lakh in 17 patients. 6 patients were undergone hemodialysis. All patients required antivenom on admission (Table 1).

\begin{tabular}{|c|c|}
\hline Parameters & Description \\
\hline Age & $\begin{array}{l}\text { Between } 14-60 \text { years. } 12(40 \%) \text { are } \\
<30 \text { yrs, } 18(60 \%) \text { patients }>30 \text { yrs. }\end{array}$ \\
\hline Gender & $\begin{array}{l}18 \text { males and } 12 \text { females have completed } \\
\text { the study. }\end{array}$ \\
\hline $\begin{array}{l}\text { Hemoglobin on } \\
\text { admission }\end{array}$ & $\begin{array}{l}11(36.7 \%) \text { have haemoglobin }<10 \mathrm{gm} / \mathrm{dl} \\
\text { on admission. } 19(63.3 \%) \text { have }>10 \mathrm{gm} / \mathrm{dl} \text {. }\end{array}$ \\
\hline $\begin{array}{l}\text { Serum Creatinine } \\
\text { on admission }\end{array}$ & $\begin{array}{l}5(16.7 \%) \text { patients have }<1.2 \mathrm{mg} / \mathrm{dl} \\
\text { on admission when } 25(83.3 \%) \text { have } \\
>1.2 \mathrm{mg} / \mathrm{dl}\end{array}$ \\
\hline $\begin{array}{l}\text { Systolic blood } \\
\text { pressure on } \\
\text { admission }\end{array}$ & $\begin{array}{l}12 \text { patients }(40 \%) \text { with }<110 \mathrm{~mm} \text { of } \mathrm{Hg}, 18 \\
\text { patients }(60 \%) \text { with }>110 \mathrm{~mm} / \mathrm{Hg}\end{array}$ \\
\hline $\begin{array}{l}\text { Diastolic blood } \\
\text { pressure on } \\
\text { admission }\end{array}$ & $\begin{array}{l}16(53.3 \%) \text { having }<70 \mathrm{~mm} \text { of } \mathrm{Hg} .14 \\
\text { patients }(46.7 \%) \text { having }>70 \mathrm{~mm} \text { of } \mathrm{Hg} \text {. }\end{array}$ \\
\hline Whole blood & $16(53.3 \%)$ were detected to have $<20$ \\
\hline $\begin{array}{l}\text { clotting time on } \\
\text { admission }\end{array}$ & secs and $14(46.7 \%)$ with $>20$ secs \\
\hline Dialysis & $\begin{array}{l}6(20 \%) \text { patients required hemodialysis as } \\
\text { part of treatment while } 24(80 \%) \text { didn't } \\
\text { required }\end{array}$ \\
\hline $\begin{array}{l}\text { Antivenom on } \\
\text { admission }\end{array}$ & $\begin{array}{l}10(33.3 \%) \text { required } 10 \text { vials, } 6(20 \%) \\
\text { needed } 20 \text { vials, } 5(16.6 \%) \text { patients got } \\
30 \text { vials } \\
\text { and } 4(13.3 \%) \text { received } 40 \text { vials }\end{array}$ \\
\hline Platelet count & $\begin{array}{l}13 \text { patients having }<100000 / \mathrm{cmm}, 17 \\
\text { patients having }>100000 / \mathrm{cmm}\end{array}$ \\
\hline (S) Sodium & All patients having $>140 \mathrm{meq} / \mathrm{L}$ \\
\hline S) Potassium & All patients having $>4$ meq/L \\
\hline $\begin{array}{l}\text { (S) Fasting plasma } \\
\text { glucose }\end{array}$ & All patients having $>75 \mathrm{mg} / \mathrm{dl}$ \\
\hline
\end{tabular}

The present study (Table 2) has clearly shown the significant decrease of serum cortisol $(\mathrm{p}=0.0014)$ and prolactin $(p=0.0001)$ levels between 3 and 6 months follow up in whole cohort whereas serum testosterone didn't show any significance $(p=0.34)$. The same trend was found among cohorts (Table 3) with (S) Creatinine $>1.2 \mathrm{mg} / \mathrm{dl}$ (For serum cortisol $\mathrm{p}=0.0241$, serum prolactin $\mathrm{p}=0.0065$ serum testosterone $\mathrm{p}=0.46$, and cohorts (Table 4) with systolic blood pressure $<110$, and/or diastolic blood pressure $<70 \mathrm{~mm}$ of $\mathrm{Hg}$ (For serum cortisol $\mathrm{p}$ value was 0.0367 , serum prolactin $\mathrm{p}$ value was 0.0187 , serum testosterone $\mathrm{p}=0.71)$.

\section{DISCUSSION}

Multiple endocrine gland dysfunctions, namely adrenal insufficiencies and hypopituitarism are commonly encountered events in practice. The incidents and causative factors are variable from region to region. ${ }^{14}$ Among the different causes, post snake bite endocrine gland insufficiencies are of significant entities in tropical countries like India. ${ }^{15}$ The present study shows significant decrease of $(\mathrm{S})$ cortisol and prolactin levels between 3 to 6 months follow up in whole study population. Vasculotoxicity after viper bite occurs due to activation of coagulation enzymes by viper venom, abnormal platelet activity and direct endothelial damage. These factors may result in microthrombi formation and shock which ultimately results in pituitary insufficiencies and adrenal failure. ${ }^{16,22}$ Amalnath D et al., ${ }^{16}$ found panhypopituitarism associated with adrenal insufficiencies in snake bite patients with vasculotoxic complications. The various pathways proposed for pituitary damage following vasculotoxic snakebite include pituitary vessels thrombosis, most probably a part of disseminated intravascular coagulation (DIC), spasm and thrombosis of pituitary vessels leading to ischemic pituitary infarction. Decreased platelet function and secondary fibrinolysis resulting pituitary haemorrhage.${ }^{10}$ Proby et al., ${ }^{23}$ observed the haemorrhagic necrosis of anterior pituitary after viper bite. Furthermore, some studies ${ }^{8,24}$ evidenced adrenal haemorrhage in addition to pituitary haemorrhage following russel viper bite.

Present study showed significant fall of (S) prolactin and cortisol in 3 to 6 months follow up patients with (S) creatinine more than $1.2 \mathrm{mg} / \mathrm{dl}$ and SBP $<110 \mathrm{~mm}$ of $\mathrm{Hg}$ and/or DBP $<70 \mathrm{~mm}$ of $\mathrm{Hg}$ at admission.

Some authors suggested about presence of microthrombi and histological evidences indicating acute tubular necrosis in kidney in addition to haemorrhagic necrosis of anterior pituitary gland in patients with 


\begin{tabular}{lcccc} 
Table 2: Hormonal profile at $\mathbf{3}$ and $\mathbf{6}$ month follow up in whole cohort & & \\
\hline Biochemical parameters & $\begin{array}{c}\text { After } \mathbf{3} \text { months } \\
\text { (Mean } \pm \text { SD) }\end{array}$ & $\begin{array}{c}\text { After } \mathbf{6} \text { months } \\
\text { (Mean } \pm \text { SD) }\end{array}$ & $\mathbf{9 5 \% C l}$ & Significance \\
\hline (S) Cortisol $(\mu \mathrm{g} / \mathrm{dl})$ & $9.22 \pm 2.03$ & $7.67 \pm 1.50$ & $0.62-2.47$ & $\mathrm{p}=0.0014^{*}$ \\
$(\mathrm{~S})$ Prolactin $(\mathrm{ng} / \mathrm{ml})$ & $10.54 \pm 2.64$ & $7.07 \pm 1.84$ & $2.29-4.64$ & $\mathrm{p}=0.0001^{*}$ \\
$(\mathrm{~S})$ Testosterone $(\mathrm{ng} / \mathrm{ml})$ & $7.15 \pm 1.92$ & $6.70 \pm 1.72$ & $-0.49-1.39$ & $\mathrm{p}=0.34$ \\
\hline
\end{tabular}

*indicates significant

Table 3: Hormonal profile at 3 and 6 month follow up with Serum Creatinine>1.2 $\mathrm{mg} / \mathrm{dl}$ on admission

\begin{tabular}{lcccc}
\hline Biochemical parameters & $\begin{array}{c}\text { After } \mathbf{3} \text { months } \\
\text { (Mean } \pm \text { SD) }\end{array}$ & $\begin{array}{c}\text { After } \mathbf{6} \text { months } \\
\text { (Mean } \pm \text { SD) }\end{array}$ & $\mathbf{9 5 \% \mathbf { C l }}$ & Significance \\
\hline (S) Cortisol $(\mu \mathrm{g} / \mathrm{dl})$ & $8.64 \pm 2.78$ & $7.01 \pm 2.67$ & $0.22-3.03$ & $\mathrm{P}=0.0241^{*}$ \\
$(\mathrm{~S})$ Prolactin $(\mathrm{ng} / \mathrm{ml})$ & $10.82 \pm 3.03$ & $8.67 \pm 2.87$ & $0.62-3.67$ & $\mathrm{P}=0.0065^{*}$ \\
$(\mathrm{~S})$ Testosterone $(\mathrm{ng} / \mathrm{ml})$ & $7.01 \pm 2.77$ & $6.53 \pm 2.4$ & $-0.85-1.83$ & $\mathrm{P}=0.46$ \\
\hline *Indicates significant & & & &
\end{tabular}

\begin{tabular}{|c|c|c|c|c|}
\hline Biochemical parameters & After 3 months (Mean \pm SD) & After 6 months (Mean \pm SD) & $95 \% \mathrm{Cl}$ & Significance \\
\hline (S) Cortisol $(\mu \mathrm{g} / \mathrm{dl})$ & $12.21 \pm 3.97$ & $10.26 \pm 3.03$ & $0.12-3.77$ & $p=0.0367^{*}$ \\
\hline (S) Prolactin (ng/ml) & $13.42 \pm 3.23$ & $11.46 \pm 3.04$ & $0.3390-3.5810$ & $p=0.0187^{*}$ \\
\hline (S) Testosterone (ng/ml) & $5.32 \pm 1.87$ & $5.50 \pm 1.97$ & $-1.1727-0.8127$ & $p=0.71$ \\
\hline
\end{tabular}

*Indicates significant

russels viper bite. ${ }^{8,23,24}$ Few authors documented the deposition of microthrombi in microvasculature was due to activation of procoagulant enzymes contained in viper venom. ${ }^{10}$ Increased serum creatinine, indicator of renal disturbances might be a direct consequences of DIC leading to prerenal failure. ${ }^{10}$ Study conducted elsewhere ${ }^{16}$ stated the pituitary insufficiency results from microthrombi formation and shock with hypotension. Russels viper venom causes activation of Factor $\mathrm{V}$ with fibrinolysis leading to DIC, resulting haemorrhage, hypovolemia and deposition of thrombin in microvasculature as well as glomerular capillaries and microangiopathic haemolytic anaemia and subsequent acute kidney injury (AKI). A direct cytotoxic action of snake venom may also develop AKI. ${ }^{25}$

Hypotension after snakebite is attributable to various venom activities including increased capillary permeability that causes extravasation of plasma and toxins acting on cardiac muscle, vascular smooth muscle and other tissues.

Several mechanisms cause shock following envenomation, these include fright, abnormal capillary permeability (Capillery leak syndrome) with relative intravascular hypovolemia, venom induced activation of kininogens, ACE inhibitors and bradykinin potentiating peptides, direct myocardial suppression, massive bleeding and thromboembolism as well as anti snake venom induced anaphylactic reactions. ${ }^{26}$
The present study observed cortisol deficiency at 6 months follow up in patients with hypotension at admission. Glucocorticoid deficiency leads to hypotension by decreasing vascular responsiveness as the steroids having permissive action on catecholamines and Angiotensin II, decreased rennin generation and increased prostacyclin production.

Pituitary necrosis due to Russel viper envenomation may be a two stage process, in the first stage pituitary stimulation and enlargement occurs due to direct effects of venom, capillary leak syndrome and hypotension. In the second stage, major bleeding may cause relative ischemia to the swollen pituitary stalk causing pituitary necrosis. This is likely to be aggravated by microvascular thrombosis due to DIC. ${ }^{27}$

The present study shows the fall of (S) cortisol and prolactin levels between 3 to 6 months follow up but (S) testosterone level didn't follow the same trend. This reflects partial hypopituitarism following snakebite. ${ }^{28}$

Furthermore, manifestations of hypopituitarism may become obvious after a long period of months or years after the snakebite event, rather called chronic hypopituitarism. ${ }^{29}$ A study conducted in Burma shows a gap of six months to twenty years between the snake bite event and onset of hypopituitarism. ${ }^{29,30}$ 
Hypopituitarism after snakebite is rare and often insidious in onset. Diagnosis is delayed since often patients present with non-specific symptoms like nausea, vomiting, lethargy and weight loss due to cortisol deficiency. ${ }^{28}$

\section{CONCLUSION}

Hypopituitarism followed by snakebite is often a missed clinical entity and compromise the life of survivors of Russel viper's envenomation. A high degree of clinical suspicion is required to diagnose the condition. Hormonal evaluation should be undertaken if clinically appropriate.

\section{ACKNOWLEDGEMENT}

The authors take this opportunity to thank Department of Medicine and Department of Biochemistry for their whole hearted support for this study.

\section{REFERENCES}

1. Warrell DA. Snakebite. Lancet. 2010; 375: 77-88. https://doi.org/10.1016/S0140-6736(09)61754-2

2. Harrison RA, Hargreaves A, Wagstaff SC, Faragher B and Lalloo DG. Snake envenoming: a disease of poverty. PLoS Negl Trop Dis. 2009;3: 569.

https://doi.org/10.1371/journal.pntd.0000569

3. Mohapatro B, Warrell DA, Suraweera W, Bhatia P, Dhingra N Jotkar RM, et al. Snakebite mortality in India: a nationality representative mortality survey. PLoS Negl Trop Dis. 2011; 5:1018.

https://doi.org/10.1371/journal.pntd.0001018

4. White J. Clinical toxicology. Curr Infect Dis Rep. 2011;13: 236-242. https://doi.org/10.1007/s11908-011-0172-1

5. Chippaux JP. Snake-bites: appraisal of global situation. Bull world health organ. 1998; 76:515-524.

6. Kasturiratne A, Wickrenasinghe AR and Desilva N. Estimating the global burden of snakebite, a literature analysis and modelling based on regional estimates of envenoming and deaths. PLoS Med. 2008; 5:218.

https://doi.org/10.1371/journal.pmed.0050218

7. Alirol E, Sharma SK and Bawaskar HS. Snakebite in South Asia: a review. PLoS Negl Trop Dis. 2010; 4:603.

https://doi.org/10.1371/journal.pntd.0000603

8. Tun P, Phillips RE, Warrell DA, Moore RA, Tin Nu S, Myint L, et al. Acute and chronic pituitary failure resembling Sheehans syndrome following bites by Russels viper in Burma. Lancet.1987; 28562:763-767.

https://doi.org/10.1016/S0140-6736(87)92500-1

9. Proby C, Tha A, Thet W, Hla M, Burrin JM and Joplin GF. Immediate and long term effects on hormone levels following bites by Burmese Russel's viper. Q J Med. 1990; 75:399-411.

10. Saxena A, Srivastava AK, Rajput AS, Tiewsoh I and Jajoo UN. Acute hypopituitarism- a rare complication of vasculotoxic snake bite: a case report. Jour of Mahatma Gandhi Inst of Med Sc. 2014; 19:144-147. https://doi.org/10.4103/0971-9903.138440

11. Reid HA and Theakston ROG. The management of snake bite. Bull world health organ. 1983; 61: 885-895.

12. Clayton RN. Mortality, cardiovascular events and risk factors in hypopituitarism. Growth Horm IGF Res. 1998; 8:69-76. https://doi.org/10.1016/S1096-6374(98)80013-0

13. Sudulagunta SR, Sodulagunta MB, Khorram H, Sepehrar M and Noroozpour Z. Generalised fatigue, amenorrhoea due to snake bite. SM J Case Rep. 2015; 1:1002. https://doi.org/10.1093/omcr/omv054

14. Chatterjee P, Mukhopadhayay P, Pandit K, Roychowdhury B, Sarkar D, Mukherjee S, et al. Profile of hypopituitarism in a tertiary care hospital of eastern India: is quality of life different in patients with growth hormone deficiency. J Indian Med Assoc. 2008; 106:384-385

15. Dhanwal DK and Das AK. Hypopituitarm following snakebite. J Assoc Physicians Ind. 1998; 46:322.

16. Amalnath $D$ and Basker $D$. Multiple endocrine gland apoplexy post snake bite. JCR. 2016; 6:479-481. https://doi.org/10.17659/01.2016.0115

17. Nelson JC and Wilcox RB. Analytical performance of free and total thyroxin assays. Clin Chem. 1996; 42:146-54. https://doi.org/10.1093/clinchem/42.1.146

18. Burger HG and Patel YC. Thyrotropin releasing hormone-TSH. Clinic Endocrinol and Metab. 1977; 6:831. https://doi.org/10.1016/S0300-595X(77)80057-1

19. Burtis CA, Ashwood ER, editors. Teitz textbook of clinical chemistry, $2^{\text {nd }}$ ed. Philadelphia, PA: WB Saunders; 1994:18251827.

20. Uotila M, Ruouslahti E and Engvall E. Two-site sandwich enzyme immunoassay with monoclonal antibodies to human alpha-fetoprotein. J Immunol Methods.1981; 42 (1):11-15. https://doi.org/10.1016/0022-1759(81)90219-2

21. Chen A, Bookstein JJ and Meldrum DR. Diagnosis of a testosterone secreting adrenal adenoma by selective venous catheterization. Fertil Steril. 1991; 55:1202-1203. https://doi.org/10.1016/S0015-0282(16)54378-7

22. Bancos I, Hahner S, Tomlinson J an Arlt W. Diagnosis and management of adrenal insufficiency. Lancet Diab Endocrinol. 2015; 3:216-226. https://doi.org/10.1016/S2213-8587(14)70142-1

23. Proby $\mathrm{C}$, Tha $\mathrm{A}$, Thet $\mathrm{W}$, Mon $\mathrm{H}$, Burrin $\mathrm{JM}$ and Joplin GF. Immediate and long term effects of hormone levels following bites of Burmese russel's viper. Q J Med. 1990; 75: 399-411.

24. Than T, Francis N, Tin NS, Myint L, Tun $P$, Sue $S$, et al. Contribution of focal haemorrhage and microvascular fibrin deposition to fatal envenoming by russel's viper in Burma. Acta Trop.1989; 46:23-38. https://doi.org/10.1016/0001-706X(89)90013-2

25. Menon JC, Joseph JK, Jose MP, Dhananjay BL and Oommen OV. Clinical profile and laboratory parameters in 1051 victims of snakebites from a single center in Kerala, south India. J Assoc Physicians Ind. 2016; 64: 22-29.

26. Jeevagan V, Katulanda P, Gnanathasan CAand Warrell DA. Acute pituitary insufficiency and hypokalemia following envenoming by Russels viper in Srilanka: exploring the pathophysiological mechanism. Toxicon. 2013; 63:78-82. https://doi.org/10.1016/j.toxicon.2012.11.012

27. Rajagopala S, Thabah MM, Ariga KK and Gopalakrisnan M. Acute hypopituitarism complicating russel's viper envenomation: case series and systematic review. QJM: An International J of Med. 2015; 168(9): 719-728. 
https://doi.org/10.1093/qjmed/hcv011

28. Rajasekharan SP, Kumar $S$ and Balachandran V. Snake envenomation: An unusual cause of hypopituitarism. Brunei Int Med J. 2014; 10(6): 334-337.

29. James E and Kelkar PN. Hypopituitarism after viperine bite.
J Asso Physicians India. 2001;49: 937-938.

30. Majeed PA and Thomas Z. Panhypopituitarism as a sequelae to snake venom poisoning - a report of 6 cases. Paper presented at the Madhura Conference. Abstracts of associations of physicians, India, 1987.

Authors contribution:

KK-Concept and design of the study, prepared full draft of manuscript, statistically interpreted and analysed; SM- Reviewed the literature and prepared the manuscript.

Work attributed to:

Calcutta National Medical College, Kolkata, West Bengal, India.

Orcid ID:

Dr Kaushik Kar- (1) http://orcid.org/0000-0002-3627-4447

Dr Sandipan Mukherjee- (i) http://orcid.org/0000-0002-2783-8810

Source of Funding: None, Conflict of Interest: None. 